\title{
Wilayat Al-Hisba; A Means to Achieve Justice and Maintain High Ethical Standards in Societies
}

\author{
Ssuna Salim
}

Senior Visiting Lecturer, University Utara Malaysia, School of Social Sciences,

Center for General Studies, Sintok 06010, Kedah Malaysia

\section{Syahrul Faizaz Binti Abdullah}

Senior Lecturer, University Utara Malaysia, School of Social Sciences, Center for General Studies, Sintok 06010, Kedah Malaysia

\author{
Assoc. Prof Dr. Kamarudin bin Ahmad \\ University Utara Malaysia, School of Social Sciences, Center for General Studies, \\ Sintok 06010, Kedah Malaysia
}

Doi:10.5901/mjss.2015.v6n4s2p201

\section{Abstract}

One of Allah's attributes is Adl or The Just, as a result Islam is a religion of justice, and consequently, a Muslim must be just. .Justice and maintenance of high ethical standards have always been among the major concern of Islamic States and societies. The concept of justice is central to the Islamic faith, in all dealings and spheres of life, this necessitated ways, means and probably institutions to oversee its implementation. This study adopted a descriptive analytical synthetic approach which was mainly interpretative in the form of textual commentary. The study mainly focuses on hisbah due to its nature of administering and covering a number of areas of public life to do justice to society. The study as a result will trace the origin of hisbah, its scope, show whether it did differ more especially in its mode of operation right from the prophetic period to the time when it ceased to function, without of course forgetting the person who carries out this job, his appointment, scope of operation and qualification. The study concludes by analyzing the necessity of hisba to the present day Muslim community's current situation

Keywords: Justice, ethical standards, Islamic states, hisbah, public life, Muslim community

\section{Introduction}

Without justice any Islamic state or society will fail to leave according to the dictates and demands of the faith thus failing to play its role as vicegerents. It is due to the necessity of maintaining justice that such institutions like Wilayat alMazalim, Wilayat al-Hisbah, the institution of qadhi were established to ensure high ethical standards and to maintain justice. Though such institutions may have appeared at a later date in Islamic history, however, this should not be interpreted as sidelining this principal during the early days of Islam. In - fact the prophet (peace be upon him) himself was the best example and the promoter of al-amr bil-maruf wa al-nahy wa al-munkar (encouraging the doing of good deeds and guarding against evil) which principal continued to be upheld to its highest expectations during the rightly guided caliphate without being institutionalized.

\section{The Literal Meaning of the Term Hisbah}

Literally the term hisbah is derived from the root word: Ihtisāb yahtasibu, ihtisābān, which carry a number of meanings; Ibn Manzūr (1990) is of the opinion that hisbah connotes hastening in acquiring rewards with patience or doing a number of good deeds in agreement with the Islamic teaching. This can be supported by a Prophetic tradition narrated by Abu Hurairah "Anyone who fasts the month of Ramadan with faith in Allah expecting rewards from Him (ihtisabān) Allah will pardon his past sins. This has an implication that whoever observes the fasting of the Month of Ramadan with full faith in Allah, hopping for His rewards, Allah will exonerate his past sins. 
On the other hand, al-Sunāmi (1986) divided hisbah into two meanings; first, counting, second guarding against.

Furthermore, according to Ahmad Che Ya'kob, (1999), the term Hisbah means al-hisāb, which denotes administration or management. The term Hisbah can also be derived from the root word hasaba, yuhāsibu, muhāsabah, which in this case means self-evaluation.

\section{The Technical Meaning of the Term Hisbah}

This concept has been exhaustively discussed by Muslim scholars of various periods in their writings, whereby they defined this concept in various ways. They generally agreed that the term al-hisbah refers to al-amr bil-ma'rüf and alnahyi wa al- munkar (encouraging doing good and stopping evil). Al-Mawardi, (1999) in discourse from the point of view of the function of hisbah officer (al-muhtasib), he defined al-hisbah as a struggle to ensure that people do good deeds, when it is apparent that such an activity is being neglected, besides guarding against evil, when it is noticed that the majority are being involved in such an activity.

It is interesting to note that Ibn Khaldūn (2012) in his Muqaddimah defines hisbah as a religious responsibility to be carried out in encouraging good deeds and guarding againt evil. Al-Syaizari (1981) agrees with Ibn Khaldun and adds that it also involves improving people's lives. Ibn Taimiyya (n.d) did not differ from Ibn Khaldun and al-Syaizari. In his book entitled "Al-Hisbah fi al-Islām" he is of the opinion that the main function of the hisbah officer is to encourage doing good deeds and stopping evil in all dealings and transactions, where it is not burdensome to the government officials, judges, and the officials of other departments.

'Abdullah Muhammad 'Abdullah (n.d) in his book entitled Wilāyah Al-Hisbah fi al-Islām, summarizes opinions of the previous scholars about the definition of hisbah. He affirms that it is the responsibility of the leader to entrust it to an individual, vesting in him the power directly to inspire people to do good when it is neglected and to guard against evil when it is widely spread among the people, as well as administering punishments to the wrongdoers in accordance to the Syariah within the limits of its jurisdiction.

Interestingly, the Jurists according to Ahmad Che Ya'kob, (1999) have defined hisbah as a government institution in which power is delegated to an individual, which power later on will be assigned to specific individual known as almuhtasib giving them the responsibility to monitor economic, religious, social activities, hygiene and, other municipal affairs and administration of a given town. The objective of this administrative obligation is to guarantee that the above activities do not contradict with the Islamic law besides implementing punishment to those who have contravened with it. Conversely, Khan (2012) concurs with Ibn Taymiyya (n.d) and technically defines hisbah as connoting the state institution to promote what is proper and forbid what is improper. Khan further accentuates that the Quran envisages every Muslim to pray a positive role in the propagation of good (ma'ruf) and suppression of evil (munkar) it has been made an obligation on a section of society to remain engaged in it (fard kifaya) and is it upon the Islamic state to institute arrangements to oversee the implementation of this injunction.

Ibn Tayymia (n.d) further describes al-Hisab as a moral as well as a socio-economic institution whose basis lies in the Quranic command of ordaining good and forbidding evil. His primary concern was the attainment of justice, on which he further emphatically clarifies that, a regime committed to justice even if it has certain moral failings is superior to a regime of pious tyranny. He went on to elucidate by stressing that, God upholds the just state even if it is unbelieving, but does not uphold the unjust state even if it believes.

It is apparent from the above definitions that hisbah is a religious duty which must be implemented by the leader, by engaging al-muhtasib charged with the task of supervising of Muslim activities in all aspects of daily life, by making sure that the Muslim community does good deeds and it guards against evil concurring with the limits imposed by the Islamic law in response to the Quranic command thus "And among you there should be a party who invite to good and enjoin the right and forbid the wrong" 3:103.

\section{Hisbah, Development and Objectives}

Ibn Taymiya (n.d) explicates that, the whole religion and authority is a matter of ordaining and forbidding, the ordaining with which Allah has sent his messenger is the ordaining of what is proper and the prohibition with which he sent him in the prohibition of the improper. This consequently formed the characteristic of the Prophet and the Believers. This was a reflection of the implication of the Quranic verse when Allah states in (9: 71) thus; "Of the believing men and women some are charge of others, ordaining what is proper and forbidding the improper" It is therefore apparent that the above verse made it a collective obligatory duty to every able Muslim, though Ibn Taymiyya stresses that it becomes an individual obligation for the able person when no one else undertakes it. 
It follows shoot that all Islamic authorities have the sole aim of ordaining what is proper and forbidding the improper, from the greater military authority to the lesser such as local authority. Others are in position of a trustee commanding obedience and what is required of them is impartiality and justice, such as the Commander, the Magistrate and the Muhtasib.

Accordingly, the ordaining of good and forbidding of evil is an integral part of religion, that Allah describes His Prophet thus, 'He ordains for them what is good and forbids them what is evil, makes wholesome things lawful to them and makes bad things unlawful" (7: 157). On commenting on the above verse Ibn Taymiyya asserts that it is an expression of the perfection of Prophet's mission. This prompted the Prophet to say: Abū Hurayrah relates that Prophet Muhammad (peace be upon him) said: "I have only been sent to perfect good moral character." [Musnad Ahmad (8595)]. In another accepted tradition the Prophet is said to have said again: "Narrated Abu Huraira that Allah's Apostle said, "My similitude in comparison with the other prophets before me, is that of a man who has built a house nicely and beautifully, except for a place of one brick in a corner. The people go about it and wonder at its beauty, but say: 'Would that this brick be put in its place!' So I am that brick, and I am the last of the Prophets." Bukhari: Book 4: Volume 56: Hadith 735.

As a consequence, through him God's religion was perfected, comprising the ordering of every right and forbidding of every wrong, the permitting of every good and the prohibition of every evil. Interestingly, the mission of ordaining good and forbidding evil is unceasing and does not rest on the Prophet alone, but it is a continuous community responsibility, this why Allah characterized the community in the same way He did characterize its Prophet, when he said: "You are the best community ever brought forth for mankind: enjoining the proper and forbidding the improper, and believing in God" (3:110). Allah says again: "The believers, men and women, are protecting friends of one another: enjoining the proper and the improper" (9:71). As a result, on the authority of Abu Huraira, the Prophet said: "You are the best of mankind for the sake of mankind, in shackles and chains, to make them enter Paradise".

Hence, the uniqueness of the Islamic Umma lies in its being most beneficial to them, supremely kind towards them, because they have perfected the enjoining on people what is proper and forbidding them what is improper, since they have commanded every right and forbidden every wrong to everyone, which they perform through struggle in God's cause with themselves and with their property, and this is the perfection of benefit for mankind. Unlike the Islamic community other communities did not enjoin everything proper upon every one, nor did they forbid to every one everything improper, nor did they strive to that end. Some of them did not strive at all, while some like the children of Israel did but their struggle was generally geared towards repelling their enemies from their land.

Khan (2012) argues that it was against this background that after the establishment of the Islamic state in Medina part of the task before the Prophet was to reshape its institutions, lay dawn norms of behavior and provide arrangement for the protection and perpetuation of these norms. Among these norms was the norm of calling upon everyone to engage in enjoining good and forbidding evil, which is reflected in a number of his traditions, let alone himself, undertaking inspections of markets to see that the merchants did not involve themselves business malpractices. Whenever he saw someone indulging in an evil he would forbid him. This function he carried out both as a Prophet of Allah and as a head of the Islamic state. In this regard, the Prophet has been termed as the first muhtasib in the Muslim history. Later, when his personal engagements increased he appointed Said b. al-As b. Umayyah as muhtasib in Makkah and Umar b. al-Khattab in Medina. This marked the initiation of the institution of Hisbah as well as laying down its principles and regulations, whose salient feature was the role of the Muhtasib and his scope of operation.

The institution of Hisbah continued to thrive during the Caliphate Period. It is reported that the first four caliphs of Islam carried out the functions of Muhtasib themselves, although there are reports of the appointment of market officer by Caliph Umar. The provincial governors during this period acted as Muhtasibs on behalf of the caliph.

A separate department of Hisbah, with a full time Muhtasib assisted by qualified staff Known as (Arifs and Amins) was introduced by Abbasid Caliph Abuu Ja'far al-Mansuur in 157 A.H. He appointed Abu Zakariaya Yahya b. Abdullah as muhtasib. Here the hisba is seen as being institutionalized, and with the expansion of the jurisdiction of the caliphate the office of the muhtasib also expanded and assumed an increased number of functions.

Khan (2012) further gives details that the institution of hisba moved along with Muslims in the western provinces of Spain and North Africa and remained an integral part of the state even after the split of the Baghdad Caliphate. Similarly, the office of muhtasib was an important department during the rule of Fatimids, Ayyubids, and Ottomans.

A further account is given by Khan (2012) that, though hisba department did not exist, a muhtasib and qadhi were appointed whenever an area was annexed to the state. But it was stunning in the case of Mughals who replaced it with the office of Katwaal who had a more limited jurisdiction than the muhtasib due to their own lax moral standards.

Khan (2012) concludes by observing that the institution of hisba remained in vogue and termed differently during entire Muslim history. In Baghdad for example, the officer in charge was muhtasib, in North Africa Sahib al-suq, in Turkey, muhtasib aghasi and in India a Katwal. Khan again illuminates that in certain cases the offices of the qadi and the 
muhtasib were entrusted to the same person while at some other places the police department (Shurta) and the hisbah were headed by the same officer and at other places the three offices were manned by one man, but the functions of muhtasib were clearly distinct. Khan's observation that the institution of hisbah remained vogue throughout Islamic history needs scrutiny, it is crystal clear that the Prophet was very clear about the importance of hisbah, he even did personally get involved in it, and this is evident in his numerous sayings. Not being institutionalized did not mean vagueness; even after his demise the caliphs continued to implement the same principles and they did not have any problem, because they had understood the role, importance and position of this institution from the Quranic verses as well as Prophetic traditions. Khan's comment may be true to a certain extent for the succeeding generation, which did not only neglect the institutionalized hisba but also generally neglected other Islamic teachings.

Finally with the advent of western colonialism most of Muslim institutions underwent drastic modifications, hisba was not an exception to this wave, thus its functions declined in its effectiveness, by disintegrating into a number of departments. By $19^{\text {th }}$ century Persia, Turkey, Egypt and India had already transformed the hisba into a number of secular departments discarding its religious content as irrelevant. In the present day Muslim societies the secular functions of hisba have been assigned to various departments of the government and the religious functions have been neglected to a secondary position. Perhaps, Saudi Arabia today is the only Muslim state, which has retained the religious wing of the hisba intact to a large extent, although it too has distributed the secular functions to different departments and ministries.

\section{The Muhtasib's Qualifications and Responsibilities}

For the institution of hisbah to be effective in carrying out its functions needed individuals to run it. Of course, the responsibility of commanding good and forbidding evil rests on the shoulder of all Muslims. But to ensure that this great task in not neglected some individuals may volunteer, but in most cases since the beginning of this institution right from the prophet they were chosen and appointed to carry out this job. A muhtasib had to be a person of great integrity and good character, not necessarily a jurist, but generally acquainted with Islamic teachings, ethics and norms; him and his team were supposed to be aware of various forms of abuse in order to effectively carry out their responsibilities.

Khan (2012) agrees to this and elaborates that traditionally, the muhtasib was a free Muslim male with a high degree of integrity, insight, reverence and social status. On the qualification of the muhtasib khan differed and asserted that, he was supposed to be a scholar of the Sharia, and on top of that adds Khan, most often competent for litihad with a high degree of in -depth knowledge in the social custom and mores. It is further asserted by Khan that of the qualities of muhtasib knowledge, kindness, and patience were considered to be of prime importance.

Ibn Taymiyya (n.d) enlightens that the muhtasib is charged with ordaining that which is fitting and proscribing the improper in those spheres not reserved to the governors, the judges, the administrative officers. Ibn Taymiyya continued and made it clear that, the duties of a muhtasib include: ordering common people to perform prayers at their proper times and punishing with flogging or imprisonment those who do not pray, supervising the prayer-leaders and those who give the call to prayer, seeing to it the former do not neglect the duties of their office and that the latter keep within the legally prescribed form. In case of inability to enforce his orders he may call upon the military, or the magistrate or anyone who commands obedience to help him.

It is apparent according to Ibn Taymiyya (n.d) that the most important responsibility of a muhtasib is to make sure that common people do not neglect their five daily canonical prayers; the reason being that, no action is more fitting than the prayer. It is the pillar of Islam and the most important of its laws, being coupled with the two professions of faith. God decreed it on the night of the Ascension, communicating it directly to the messenger rather than sending it by angelic envoy.

The Quran mentions it very often, explaining its position, thus, it was the last bequest of the Prophet, and on him be peace. It was due to this, that the commander of the faithful Umar ibn al-khattab, may Allah be pleased with him, used to write to his governors that for him the most important part of their duties was the prayer. Whoever keeps to it and observes it will preserve his faith, whoever neglects it commits the gravest omission of all.

On this Kamaruddin (1992) affirms that the official duties of al-muhtasib were to enforce Islamic morals and religious behavior on the community. His role was to oversee that the five daily prayers are performed on time, that the fasting on the month of Ramadhan is observed, and that everyone lives a modest life by strictly following the code of morality; no free mixing between different sexes in streets and public places. The maintenance of the mosque according to Kamarudin was under this control.

Khan (2012) agrees with Ibn Taymiyya ( n.d) and further divided the function of a muhtasib into three categories: those relating to the rights of God, which covered religious activities such as punctuality of prayers, organization of Jum'a and ' $l d$ congregations and maintenance of mosques. Those relating to the rights of people, this is related to community 
affairs and behaviors in the market, such as accuracy in weights, and measures and honesty in dealings. Those relating to both, this was mostly related to affairs relating to municipal administration such as keeping the roads and streets clean and lit at night and preventing the building of factory or dwelling place which could damage the community interests.

According to Khan (2012), the muhtasib could appoint technically qualifies staff who could investigate the affairs of different crafts and trade. He also received complaints from the public but could also initiate an investigation on his own. He was supposed to use his wide power sensibly and he had to take a number of steps, give advice, reprimand, rebuke, obstruction by forces, threat, imprisonment, and expulsion from the town. He could choose a stronger punishment only when a wilder one seemed to carry no weight to the person concerned.

Muhtasib's code of conduct asserts Khan (2012) provided a system of checks and balances, for example, he could not doubt a prima facie approved behavior nor could he engage in secrete probing into a doubtful affair. He could only intervene if the behavior of a person obviously went against the Sharia and he could not punish people, but he could forbid them from those actions, which had a consensus of the Umma. He could only act with wisdom, foresight and not overzealous and his actions were not to involve a greater mischief than the one he wants to obviate, thus, he needed to make sufficient arrangements to annihilate an evil of a powerful group to counter their reactions effectively. He could invite community participation for social convenience, not to impose his personal opinion on the majority.

It is apparent that, muhtasib's rights and functions were divided by Khan in at least three strands, which appeared quite distinctly. The muhtasib was responsible to see that the community as whole had a proper organization and facilities for performance of Ibadat, the maintenance of mosques, appointment of muazzins and imams, arranging daily prayers, Friday congregations and Id prayers, and he would object to any willful and volitional non-observance of any other obligation of the Sharia by individuals or community.

On the other hand the muhtasib was concerned with the implementation of adl (justice) in the society. He tries to enforce fair play among different economic factors to minimize possibilities of exploitation from the economy, thus, inspection of weights, and measures, metallic content of coins, and quality of food products. He would also check on the prices, supplies and production, monopolistic collusions, cheating, fraud. He had to intervene wherever the economic flows were manipulated by the economically powerful individuals or groups to their selfish ends.

The third aspect is where the muhtasib paid special heed to various municipal services especially hygienic conditions in the town, perhaps the muhtasib was the only municipal officer in the Muslim society. He would look into the entire municipal administration such as street lighting, removal of garbage, architectural designs of buildings water supply and antipollution sanctions.

\section{Relevancy of Hisba to Contemporary Muslim Communities}

A cross sectional analysis of historical facts about hisba right from its inception till the time it lost its religious function, is an evidence that nobody doubts or denies its role in ensuring justice, the central concept to the teachings of Islam. The act of ordaining good and forbidding evil reduces malpractices and ensures justice to all, irrespective of people's status, thus, the Prophet, peace be upon him was directly involved, hence, serving as a role model to his companions who inherited the same legacy which they seriously implemented, consequently, contributing to their maintenance of justice to its highest standards. Even succeeding generations, that viewed hisba seriously were able to keep justice and to curb malpractices to a greater degree. It was only when this institution lost its Islamic function that the contemporary Muslim communities suffered from all sorts of evil, ranging from negligence of their major obligations to rampant cheating and fraud, as a result compromising justice. It is due to this fact that though certain aspects of hisba are still maintained in form of assigning some of its functions to government departments and ministries, it lost its religious function, thus, becoming ineffective. This marginalization and negligent of this institution, has resulted into Muslim countries ranking higher on the secular list of corruption. This is a great pity and a shame to the community that was chosen by the Almighty as best due to its ordaining of good and forbidding evil.

\section{Conclusion}

The institution of hisba was a Muslim contribution to Islamic civilization, though some people allege that it was a copy cut from the Greek, neglecting the fact that its basis is be found in the holy Quran. This is why, much of what used to be done by a muhtasib is still done by government department or ministries, at times more efficiently, but lurking in terms of the Islamic input, which was based on the concept of piety and being watched and observed by the Almighty Allah. Thus, the main objective of ensuring justice to the community is no longer the concern of the present day so called institutions for fair dealings and protection of common interests, but the protection of big companies by governments at the expense 
of justice and well fair for all, the main agenda of hisba

\section{References}

'Abdullah Muhammad 'Abdullah, (t.t), Wilayah al-Hisbah fi al-Islam, al-Qahirah:Maktabah Syu'ara'

Ahmad bin Che Ya'Kob, (1999), "Institusi Hisbah: Suatu Pengenalan", Jurnal Fikrah, Shah Alam: Unit Pendidikan Persediaan UiTM

Al-Mawardi, Abu al-Hasan 'Ali, (1999), al-Ahkam al-Sultaniyyah, Beirut: Dar al-Kutub Ilmiah

Al-Sunami, 'Umar Ibn Muhammad, (1986) Nisab al-Ihtisab, Tahqiq Maizan 'Asiri, Makkah al-Mukarramah: Matba'ah al-Thalib

Al-Syaizari, 'Abd al-Rahman al-Nasr, (1981), Nihayah al-Rutbah fi al-Talab al-Hisbah, Tahqiq Dr. al-Sayyid al-Bar al-'Arabi, Lubnan: Dar al-Thaqafah

Ibn Khaldūn (2012). The Muqaddimah. Trans by Franz Rosenthal. https:asadullaahali. Files. Wordpress.com/2012/10/ibn_khaldunal_muqaddimah.pdf.

Ibn Manzur Jamal al-Din Abu Fadhl Muhammad Jalal al-Din Abu 'Azm Mukarram

Ibn Najib al-Din. (1990). Lisan al-'Arab, cet. 1, Beirut: Dar al-Sadir

Ibn Taimiyyah, Taqiyyu al-Din, (n.d), al-Hisbah fi al-Islam, Kuwait: Dar al-Arqam

Khan, Muhammad Akbar, The Institution of Hisba (Ombudsman) and Consumer Protection in Hamdard Islamicus , Jul-Sep2012, Vol. 35 Issue 3, p57-87, 31p. Publisher: Hamdard Foundation.

Kamarudin Bin Ahmad. (1992). The Qualifications and Role of the Qadi in Kedah, Malaysia. A dissertation presented to the University of St. Andrews for the Degree of M. PHL. (A). 